Article

\title{
Rescue US: Birth, Django, and the Violence of Racial Redemption
}

\author{
Joseph Winters \\ Religious Studies, Duke University, Durham, NC 27708, USA; jrw@duke.edu \\ Received: 19 December 2017; Accepted: 8 January 2018; Published: 12 January 2018
}

\begin{abstract}
In this article, I show how the relationship between race, violence, and redemption is articulated and visualized through film. By juxtaposing DW Griffith's The Birth of a Nation and Quentin Tarantino's Django Unchained, I contend that the latter inverts the logic of the former. While Birth sacrifices black bodies and explains away anti-black violence for the sake of restoring white sovereignty (or rescuing the nation from threatening forms of blackness), Django adopts a rescue narrative in order to show the excessive violence that structured slavery and the emergence of the nation-state. As an immanent break within the rescue narrative, Tarantino's film works to "rescue" images and sounds of anguish from forgetful versions of history.
\end{abstract}

Keywords: race; redemption; violence; cinema; Tarantino; Griffith; Birth of a Nation; Django Unchained

Race, violence, and the grammar of redemption form an all too familiar constellation, especially in the United States. Through various narratives and strategies, we are disciplined to imagine the future as a state of perpetual advancement that promises to transcend legacies of anti-black violence and cruelty. Similarly, we are told that certain figures or events (such as the election of Barack Obama) compensate for, and offset, the black suffering that conditions and organizes modern life. When Barack Obama responded to the acquittal of George Zimmerman by reminding the world that despite the death of Trayvon Martin, the legal system works and each generation continues to progress, he placed Martin's death in a redemptive schema. ${ }^{1}$ Here the rhetoric of progress supersedes death and suffering and attempts to "rescue" us from the constitutive quality of racial antagonisms. ${ }^{2}$ Conversely when the Trump regime revives the mantra "Make America Great Again," the eye of redemption looks backward and yearns to recuperate a time of plenitude that has been "taken away" by people of color, immigrants, queers, non-Christians, etc. In both cases, for the liberal and conservative, redemptive logics combine deliverance-from the complexities of history—with restoration-whether the restored object is the past or a collective trust in the ever-improving present and future. And in both cases, redemption relies significantly on the endurance and justification of anti-blackness, among other conditions.

In what follows, I take seriously how film both enacts and upends this enduring relationship between racial violence and redemption. ${ }^{3}$ (Following Kara Keeling, I take film to be more than just a reflection of the social order or a representation of real life events and interactions. ${ }^{4}$ Rather as Keeling suggests, cinema is productive; it generates desires, affects, perceptions, fantasies, and alternative ways of relating to the world.) By specifically returning to DW Griffith's controversial 1915 film The Birth of a Nation, I interrogate how a collective nostalgia for a harmonious, antebellum United States involves

1 On this insidious process, see (Warren 2015).

2 Here I am thinking with Frank Wilderson's distinction between antagonism and conflict, the former being a constitutive and fundamental/ontological incompatibility between the human and blackness while the former is an obstacle than can be resolved through practices of recognition and inclusion. See (Wilderson 2010).

3 On the relationship between film, redemption, and race (in a film like Rocky) see (Martin 1995).

4 See (Keeling 2007). 
the elimination of black people-a process that is deemed necessary because blackness is imagined as the source of discord and conflict. Griffith's film sacrifices black bodies and renders acceptable the extrajudicial violence of the Klan in the name of rescuing and restoring the nation, or a particular image of the nation. While the film's logic appears seamless, I contend that Birth's attempt to resolve certain tensions and antagonisms does not work; something vital remains and haunts the film's salvific movement. To broach the film's contemporary relevance, I juxtapose Birth of a Nation with Quentin Tarantino's 2012 film, Django Unchained. Responding to Griffith's film and its legacy, Tarantino's film, I argue, inverts the redemptive logic visualized in its predecessor. If Birth of a Nation explains away the violence of slavery and anti-blackness for the sake of rescuing and protecting white sovereignty, Django Unchained uses a romantic rescue narrative to direct our attention to the violence and horror of white supremacy. In doing this, Tarantino's film exemplifies what Walter Benjamin calls weak redemption, an attempt to seize images and scenes of anguish from linear, and forgetful, visions of history. ${ }^{5}$

It is difficult to talk about race, film, and history without a discussion of The Birth of a Nation. As Ed Guerrero points out, "Because of its antiblack depiction and systematic, overt racism, it remains the most controversial film ever made." ${ }^{6}$ Infamous for using the stereotypical personas that film historian Donald Bogle examines, the film imagines a stable distinction between good and devoted blacks (mammy and uncle tom) and violent and rebellious blacks (black buck and mulatto). ${ }^{7}$ The latter are largely blamed for the downfall and decline of the South during and after the Civil War, a predicament that prompts and justifies the emergence of the Ku Klux Klan. In addition, most of the black characters in the film are white actors in black face, reminding the viewer of a legacy of black-face entertainment that both excludes and includes black people, that needs representations of black people but only insofar as black bodies are absent, parodied, or confined to a proper place. ${ }^{8}$ While The Birth of a Nation is renounced for its racist images and content, many look at this film as an artistic masterpiece. More specifically, filmmakers and critics laud Griffith for introducing ground-breaking cinematic techniques and strategies. According to Bogle, "In almost every way, Birth of a Nation was a stupendous undertaking, unlike any film that preceded it. ... It altered the entire course and content of American moviemaking, developing the close-up, cross-cutting, rapid-fire editing, the iris, the split-screen, and realistic and impressionistic lighting. Creating sequences and images yet to be surpassed, the film's magnitude and grandeur swept audiences off their feet." ${ }^{\prime 9}$ According to Bogle, one might be able to appreciate the artistic qualities of the film while rejecting its racist ideas and depictions. Yet this distinction doesn't hold so well, considering, for instance, how the lighting in the film, the juxtaposition between light and dark, reinforces a dualism between whites/good and blacks/evil. ${ }^{10}$ Form, style, and content are intertwined. While Bogle focuses on the new artistic possibilities that Griffith's film enabled, I want to suggest that by returning to this film a century after its release, we might experience the film anew, approaching it with different questions and interpretations. For instance, we might think about the difficulties involved in watching a silent film in the twenty-first century, how watching a silent film can be an onerous experience for viewers accustomed to audible dialogue accompanying the moving image. Without this dialogue, music, facial expressions, body language, bodily interactions, and captions take on a heightened importance in shaping the narrative. These aspects of the film invoke different affects, emotions, and modes of attunement. More specifically, the captions and inter-titles in the film interrupt the viewing experience, demanding a different kind of attentiveness than films with audible dialogue. Perhaps a silent film that

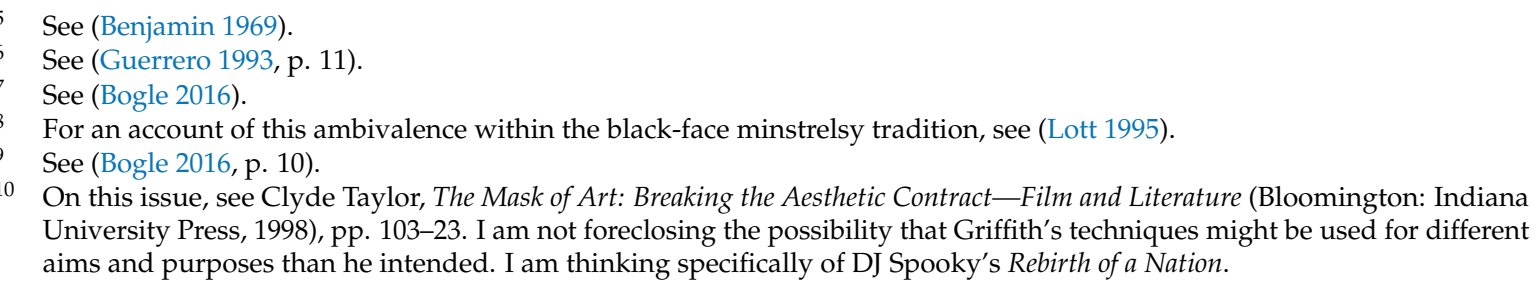


intentionally foregrounds cutting-edge cinematic techniques prompts the viewer to contemplate and experience race, gender, history, and violence differently. Alongside these possibilities, I am interested in how this film visualizes redemption and the yearning to revive white sovereignty. Consequently, I demonstrate how The Birth of a Nation induces nostalgia for the antebellum South in order to anticipate an auspicious future, a future that entails the erasure of "threatening" black bodies.

The Birth of a Nation intends to display the loss and agony produced by war, specifically the American Civil War. ${ }^{11}$ Tinged with melancholy and wistfulness, the film attempts to generate sympathy and compassion for the South. In order to accomplish this, the film represents the antebellum South as a harmonious, ordered society where denizens, including black slaves, know their place. The film suggests that this general accord is threatened and undermined by abolitionists and Northern interlopers who demand racial equality. The early sequences show images of the Cameron family in South Carolina living cheerfully-we see, for instance, Ben Cameron frolicking with his younger sister, Flora, while the Mammy character watches their playful interaction with delight and enthusiasm. When the Stoneman brothers visit from Washington, we notice an immediate connection and intimacy between the two families. Specifically, Phil Stoneman and Margaret Cameron experience an instantaneous attraction to one another; Tod Stoneman and the younger Cameron brother tease each other and play aggressively, foreshadowing the later battle scene in which they die in each other's arms; Ben Cameron falls in love with a picture of Elsie Stoneman whose physical absence heightens Ben's longing and desire for his idealized object of affection. As the viewer follows the characters sauntering through the plantation, we also observe slaves in the background laboring and collecting cotton. For a brief moment, the camera juxtaposes the leisure, play, and pleasure enjoyed by the Camerons and Stonemans against the toil performed by black bodies, bodies that appear to be content with their situation. This moment is followed by a "two hour work interval" for the slaves, free time occupied by dance, music, and hand-clapping. This scene suggests that these slave practices and activities are done primarily for the amusement of white spectators, to satisfy the desires and curiosities of the Camerons and their Northern visitors. The film's depiction of slave life on the plantation invokes WEB Du Bois's rejection of the general assumption that the spirituals make slaves sound happy, jovial, and free of sorrow, frustration, and disappointment. ${ }^{12}$ The film argues that slavery was a good thing for blacks; it civilized them and placed them within the proper order of things. ${ }^{13}$ As Guerrero points out, Birth of a Nation is part of the plantation film genre, an early twentieth century cinematic tradition that underscores the virtues and values of the genteel South and that "conforms to ideas about the benevolence of the plantation and slavery." ${ }^{14}$ In order for Griffith to invoke nostalgia, lament and sympathy for the South, he depicts the plantation as an idyllic place and the Southern past as a time marked by plenitude, harmony, and happiness.

Among other groups, Birth of a Nation ascribes blame to Northerners, abolitionists, and radical reconstructionists for the destruction of the South and the erosion of traditional ways of life. In the film, the congressman Austin Stoneman is held responsible for contributing to the erosion of order and harmony in the South. The film maligns him for spreading radical ideas to black people and by giving black men—and women-power during and after the war. But the film also suggests (in one of the opening captions) that the entrance of black bodies onto the nation's soil was the initial source of discord; the very presence of blackness anticipates chaos; blackness in the film is a signifier of disorder. And this foreign disorder can only be managed under the control and supervision of white people. As Bogle writes, "Griffith seemed to be saying that things were in order only when whites were in control and when the American Negro was kept in his place." ${ }^{15}$ Several scenes in the

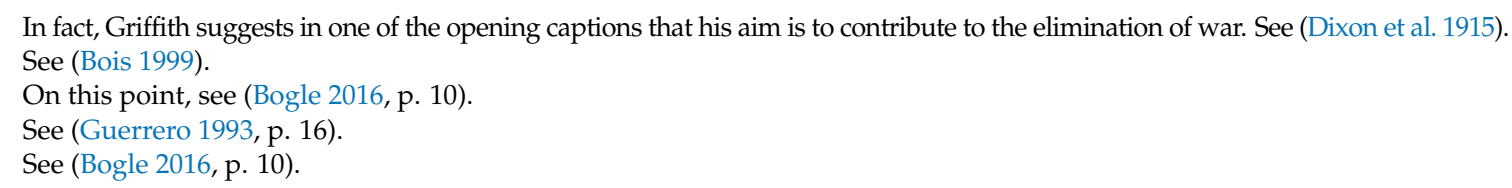


film reinforce this idea that blackness represents a threat to the order of things. Think for instance of the early scene that introduces Austin Stoneman's mulatta servant, Lydia. Lydia is depicted as a conniving servant, a trickster who devises schemes to undercut white people's authority. Unlike the slaves living on the Cameron plantation, she is unsatisfied with her servile condition. Her facial expressions indicate anger, sorrow, frustration, and even disgust (she spits at Stoneman's guest after he departs). She practices mundane forms of resistance, exemplified when she intentionally drops the guest's hat but acts as if this was an inadvertent blunder. Lydia's devious demeanor is sexualized in an explicit manner; we observe her touching herself and licking her fingers as she dreams of ways to seize power. As Stoneman caresses her exposed shoulder, the viewer gets the sense that Lydia's subtle erotic power seduces the congressman, exploiting "the great leader's weakness that will blight a nation."16 Lydia, in other words, is behind Stoneman's eventual resentment toward the South. Like Silas Lynch, the abusive leader introduced during the film's depiction of reconstruction, Lydia represents the tragic mulatto, a figure that is always the site of contradiction and confusion. ${ }^{17}$ Through characters like Lydia and Lynch, the film makes an argument against miscegenation, against the mixing of races. This combination, as Lydia supposedly shows us, can only lead to disorder and chaos. Race-mixing is a threat to whiteness and national identity; it threatens to contaminate the purity that Griffith associates with traditions and practices of the Old South.

In addition to Lydia, the "renegade black soldier" Gus is an embodiment of this chaotic threat to the South and the nation more generally. Gus is one of the Union soldiers who is given power and authority during Reconstruction, a period that inverts the hierarchy between whites and blacks according to the film. After the abolition of slavery and the conferral of citizenship rights to black men, black men are placed in prestigious positions with the help and support of resentful Northerners. Black men, soldiers and politicians especially, abuse their recently acquired power; they enact revenge on white men; they pass laws that divest whites of power and authority; they use brutal violence and coercion to secure and maintain hegemony. Blacks have taken something away from families like the Camerons; the Camerons have been dispossessed of power, tradition, and antebellum ways of life. While the Camerons, prior to the Civil War, are depicted as benevolent, caring, and compassionate, the black leaders during Reconstruction are characterized as sinister, conniving, aggressive, and sexually ravenous. (Interestingly, the only black characters that are implicitly lauded in the film are the slaves/servants who remain loyal to the Camerons.) Gus's nefarious behavior is therefore a product of this inverted hierarchy introduced during Reconstruction. In a well-known sequence toward the end of the film, Gus aggressively pursues Flora Cameron, revealing his desire to marry her. Because of his newly acquired position of power, Gus assumes that Flora is obligated to accept his offer/demand. When she refuses, Gus stalks, haunts, terrorizes, and chases Flora Cameron through the woods. Flora is so horrified by Gus that she jumps off a cliff, valiantly accepting her death and fate. The film indicates that Flora sacrifices her life to maintain her innocence and purity in the face of black male sexual aggression. To out this differently, her death is rendered meaningful when it is identified as a sacrifice for the sake of female purity, the Southern order, and so forth. In this disturbing scene, Gus takes on the qualities that define the black buck persona, embodying traditional fears and anxieties about black male desire for white women. He is a vivid reminder of how race, gender, and sexuality have always formed a complicated constellation within the modern world. As Bogle points out, "Bucks are always big, badd niggers, over-sexed, and savage, violent, and frenzied as they lust for white flesh.... Among other things, he reveals the tie between race and sexism in America. Griffith played on the myth of the Negro's high-powered sexuality, then articulated the great fear that every black man longs for a white

16 See (Dixon et al. 1915).

17 See (Bogle 2016, pp. 9, 14-15). Bogle suggests that Lydia is actually one of the film's more complex and passionate characters despite her exaggerated qualities. 
woman.... Griffith played hard on the so-called bestiality of his black villainous bucks and used it to arouse hatred."18

In a later scene, Gus is captured, placed on trial, and lynched by the recently formed Ku Klux Klan. Although the viewer never witnesses an actual lynching, we see Gus being constrained and held down by members of the Klan with a cross smoldering in the background. This shot is followed by an image of the Cameron family grieving over the dead body of Flora as if to reinforce the need for vigilante justice and to garner audience support for the act of lynching. Lynching, in other words, is depicted as a legitimate response to and compensation for black male sexual violence. After a caption reads "Guilty," members of the Klan dump Gus's corpse on the steps of Silas Lynch's house. As this sequence suggests, the Klan's main purpose is to restore order to the South, a task that involves the protection of white women from the violent lust of black men. But matters are a bit more complicated. Following the Flora/Gus segment of the film, we observe a Klan ritual in which Ben Cameron dips the group's flag into a cauldron of blood, presumably that of Flora Cameron. A caption reads: "Bretheren this flag bears the red stain of the life of a Southern woman, a priceless sacrifice on the altar of an outraged civilization." ${ }^{19}$ According to Linda Williams, this scene shows how white male solidarity revolves just as much around the sacrifice of the white female body as it does around the sacrifice/lynching of black male bodies. ${ }^{20}$ The lynching ritual, which reached its peak between 1880 and 1920, was designed to contain the sexual desires of black men and white women. While the burning, torturing, and castration of black males served to restore and maintain a patriarchal order, the film suggests that this order also requires the sacrifice of Flora/white women to keep them in their proper place; Flora's death/sacrifice is a kind of warning to white women, a reminder of the boundaries of erotic desire and attachment. Williams rightly states, "The constant threat of rape was not simply a rationalization used to obscure the real function of keeping black men in their place, it was a way to keep white women in their place.... Thus it is in a very real sense that the white woman is sacrificed 'on the altar of outraged civilization'. White men need her to be sacrificed to keep both blacks and women in their place."21 While it might seem that lynching was a means to punish black men and protect white women, if Williams is right, this horrifying ritual might have been a way to protect white men/patriarchy from the potentially unmanageable desires and actions of both blacks and women. ${ }^{22}$

What is significant here is that the film ascribes hypersexual qualities exclusively to characters like Gus, Lydia, Silas, and Flora-the latter masking a dark sexual side that is in danger of being unleashed by the black buck. Similarly, the threat of violence and rape is exclusively attached to black bodies in the film. The white men, especially those in the South, are recipients and not agents of unjust violence; the violence enacted by the Klan is therefore acceptable and deemed necessary because of its restorative function, because it supposedly protects and saves the nation from the black menace. The tragic irony here is that mulatto characters like Silas Lynch and Lydia are visible reminders of a legacy of white men using and coercing black women to satisfy sexual desires and reproduce slave labor. As Williams puts it, referring specifically to the black buck persona, "The myth of the bestial black rapist transferred the focus of sexuality from the white man's quasi-sanctioned (because economically productive) sexual activities with black women to the spectacularized bodies of black men."23 The language of "transfer" in this passage is relevant because it signifies that something unfavorable and undesirable has been relocated or redirected from one object to another. Michael Rogin points out that by locating the mulatto subject in the North and associating the mulatto with Northern vice and impropriety, Griffith is able to "move the interracial union [and violence] from the South to the North." ${ }^{24}$ As suggested

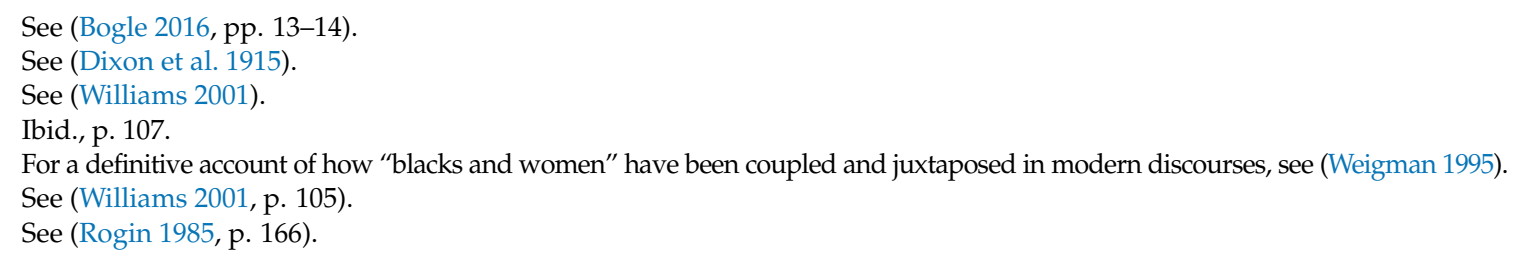


above, the film relies on a narrative of lost harmony, a depiction of the old South and plantation life that denies and displaces the horror and trauma of slavery. The origins of unrest and discord lie elsewhere-unconstrained black desire, Africa, "uncivilized" peoples, and abolitionists. In other words, for Griffith's argument to work, to make the viewer sympathize with the activities and aims of the Klan, one must accept his narrative of decline, his depiction of an idyllic, well-ordered South that thrived without violence, rape, and coercion prior to the Civil War and the abolition of slavery.

While the Klan becomes the agent/bearer of redemption, the film implies that a weaker form of redemption might be gleaned from Griffith's depiction of the agony and destruction caused by war. Recall that Benjamin's weak form of redemption involves seizing a moment/event of the past that is always in jeopardy of being used to foster agreement with the status quo. After the release of The Birth of a Nation, sympathetic commentators used language similar to Benjamin by saying that Griffith "ripped" a piece of the past and made it relevant for the present. ${ }^{25}$ By showing images of war, death, loss, and destitute communities affected by the war-images accompanied by evocative, pathos-eliciting music-Birth works to undercut narratives that underscore the achievements and triumphs of the Civil War while forgetting the losses and erasures involved in war. Any war, even if it is fought to eliminate an injustice, is tragic, a quality that cannot be easily affirmed or redeemed even if the victors are on the side of Justice. ${ }^{26}$ One tragedy cannot compensate for or cancel out another tragedy (the war doesn't redeem slavery and the traumatic dimensions of slavery don't permit forgetting or denying the devastation that the South incurred even though the war helped bring about the end of slavery). But of course a strong form of redemption supersedes this weaker form in Griffith's film. Confirming Benjamin's concerns, Griffith places the war in a strong redemptive narrative; the war and the devastation of the South both necessitate and justify the emergence of the Klan, lynching of black bodies, and the re-establishment of white supremacy. The Klan's redemptive violence restores order and unity; because of this ostensibly just and legitimate aim, the erasure of black bodies, bodies that represent chaos and violence, is rendered acceptable, even laudable. In this case, war and agony are not portrayed to challenge existing arrangements and ways of thinking; rather the war is merely a precursor to the rebirth of a nation; it is depicted as an evanescent break in the order of things, a break that is fixed and remedied by the re-establishment of white sovereignty.

As I have argued, the trope of redemption carries with it the notion of being rescued from something undesirable. In the final scenes of the film, the Klan carries out several rescue missions that reinforce the idea that whites are under siege, that black men have used their newly acquired power to terrorize whites and hold them hostage. In one sequence, the Klan rescues the residents of Piedmont from black mobs and soldiers. This rescue includes Ben Cameron saving Elsie Stoneman and her father from Silas Lynch, who in an earlier scene forced himself on the congressman's daughter and afterwards had her bound and gagged. What is notable in these succession of shots is the ways in which the Klan members ride through the town in a daunting, triumphant manner while the black mobs, after unsuccessful attempts to defeat the hooded horsemen, scatter wildly and in fear. As Rogin astutely points out, these battle scenes are very different from the Civil War battle depictions. Whereas the Civil War scenes are filled with shades and shadows (making it difficult to distinguish between North and South), the Klan rescue occurs through a stark contrast between white/light and black/darkness, between the Klan and black mobs, between good and evil. One cannot avoid the conclusion that Griffith wants the viewer to imagine the Civil War as an internal conflict between estranged families and friends while perceiving the conflict between the Klan and black soldiers as a Manichean struggle. This explains why the Civil War segment consists of poignant images of suffering, pain, and loss

25 See (Williams 2001, p. 98).

26 Who is on the side of Justice, of course, will always be a matter of interpretation. History is a battlefield of competing, clashing readings, interpretations, and power-moves. I am not reducing history to power and interests, nor am I saying that we shouldn't try to adjudicate between good and bad interpretations of history, or between just and unjust actions. I am saying that any reading of history will involve interests, biases, fantasies, and what Nietzsche calls "the will to power". 
that are designed to induce empathy, whereas the Klan riding scenes are characterized as a sweeping force eliminating evil. ${ }^{27}$ The final rescue scene repeats these contrasts as the Klan saves a group of besieged whites, including Phil Stoneman and members of the Cameron family, who have retreated to a rural cabin in order to escape the "barbaric" black hordes. As Williams points out, the use of the $\log$ cabin is significant because it reinforces the film's "nostalgia for a democratic and humble 'space of innocence.'" 28 She adds that the cabin specifically invokes Abraham Lincoln's humble beginnings. This makes sense since the film depicts Lincoln in a sympathetic manner, suggesting that without his untimely death, things would have turned out differently for the South and the nation in the period immediately after the war. If this cabin is a site of innocence, it is also a site of re-union between the North and the South (the cabin is inhabited by two Union veterans). While the Camerons, Phil Stoneman, and the cabin residents fight unsuccessfully to hold off the black invaders, the Klan appears to the sound of triumphant music to save the day. One caption puts it well: "Former enemies of North and South ... reunited again in common defense of their Aryan birthright." The North and South have reconciled their differences and this reconciled state is brought about by liberating, and defending, the South from rebellious blacks while re-admitting loyal, devoted blacks like the Mammy.

The visualization of redemption and being saved is intertwined with Christianity in the film. The image of the burning cross and the crosses stitched into the Klan uniform demonstrate the historical connections between religion and racial subordination. As Du Bois and others point out, there is a hoary tendency to conflate whiteness and the sacred, a conflation that takes on different expressions and forms, and that has been used to enact and exonerate horrific acts of violence. As Winthrop Jordan points out, early settlers often defined themselves against black slaves on the basis of religion. ${ }^{29}$ Blacks were located on the pejorative side of the Christian/heathen distinction; civilizing these "heathens" often included baptism into Christian faith and practice even if this did not translate into tangible freedom for blacks. Religion, as Griffith's film demonstrates, is a site through which racial hierarchies are fabricated and sanctioned. In one of the film's opening shots, we see an image of three back-bent slaves juxtaposed with two white men carrying whips and a praying minster on an auction block. This shot provides a powerful visualization of the relationship between religion and violence, showing how the kidnapping and coercion of black bodies was enabled by theological practices and ideas. The fact that the prayer occurs on an auction black (a space where bodies are exchanged, sold, possessed, owned, inspected, invaded) suggests that discourses about and invocations of God cannot escape the world's broken conditions and spaces, features that some people attempt to cushion God from by making distinctions between the spiritual and physical, the soul and the body, or the eternal and the temporal. After this auction block scene, we observe an abolitionist meeting in what looks like a church, reminding the viewer, perhaps against Griffith's intentions, of the role that Christianity has played in movements of resistance, struggles for black freedom, and so forth. Yet the fact that the central character in this scene is a black child also invokes historical tendencies to reduce black people to children, an association that often led to paternal relationships between white abolitionists and black people.

Another provocative religious image is introduced at the end of the film. After "peace" has been re-established, we see a spectral image of a white Jesus emerging in the midst of what looks like a Greco-Roman-style festive gathering. The film suggests that this Jesus image is an object of Ben and Elsie's wistful imagination as they honeymoon and embrace at the edge of a mountain that looks off into the sea. Their honeymoon symbolizes the reconciliation of the South and the North; the edge of the cliff/mountain motif is significant because it invokes and redeems Flora's leap from

27 See (Rogin 1985, pp. 178-80).

28 See (Williams 2001, p. 115). The cabin also conjures up stories about Abraham Lincoln's beginnings, a figure who is depicted sympathetically in the film. The film suggests that if he had not been assassinated, many of the "radical" policies associated with people like Thaddeus Stevens (who Austin Stoneman's character is inspired by) would never have been implemented.

29 See (Jordan 1968, pp. 91-98). 
the cliff (reassuring us that white women are now secured from the black male threat) and because the cliff/edge and vision of the sea suggest that the future is one of possibility now that blackness has been contained. Yet the vision of the sea invites alternative readings and interpretations. As Christina Sharpe recently reminds us, the sea, especially when associated with the Middle Passage and the logistics of the slave ship, conjures up memories of kidnapping, the torture of black people, and black bodies being thrown (or escaping) into the ocean. ${ }^{30}$ But Griffith doesn't permit these memories to upset his happy vision of a South reborn. The juxtaposition of the spectral Jesus and the palpable intimacy between Ben and Elsie, or the North and the South, is designed to drive home the theme of reconciliation, a process that entails the elimination of threatening blacks and a restoration of antebellum-style white supremacy. This process of elimination involved a conflation of any rebellious, subversive activity by black people with the exaggerated actions and characteristics of the black buck and the tragic mulatto. The relationship between restoration and eliminating danger is confirmed by an earlier shot that shows the Klan successfully intimidating a group of black men on election day, thereby anticipating the emergence of Jim Crow laws and codes. And according to the strange, but evocative juxtaposition of images at the end of the film, this moment of getting rid of black bodies, of preventing black bodies from further disturbing the political and social order, signifies and exhibits Christ's redemptive gift to humanity.

As Michael Rogin reminds us, it is important to think about Birth's historical context. Many important events and developments form the historical backdrop of this film's release-America's emerging presence as an imperial power during the early part of the 20th century, especially in relationship to places like Puerto Rico, Guam, and the Philippines; the beginning of World War I; struggles by organizations and activists to get legislators to pass an anti-lynching bill; struggles for women's suffrage. Griffith's film imagines and re-narrates the re-birth of America, of white supremacy, at a moment when America's international influence was expanding and in the era of "progressive" reform within America. At a juncture suffused with both promise and danger, Griffith suggests that progress and the vision of a more just future are informed by how we remember and interpret the past. For Griffith, progress and nostalgia are intertwined.

While we tend to think of progress as future directed and nostalgia as a desire directed toward the past, Linda Williams argues in her discussion of melodrama that the theme of restoration, the attachment to an ideal past, can be used to project and imagine a more unified future. ${ }^{31}$ In Birth, a harmonious future entails a return to the pre-war order and hierarchy between whites and blacks. But as I have suggested, the desire for restoration, the longing for an idyllic, golden age, always relies on a denial or transfer of tensions, conflicts, and tragedies that cannot be harmonized or assimilated into a coherent picture of the past and present. Griffith, as discussed above, relocates the violence and trauma of slavery to other social bodies, communities, and personae. The depiction of slave life as happy and benevolent denies the coercive quality of this institution. Beginning with the auction block, a visible but downplayed site of terror in the film, both intimates and downplays the Middle Passage and the kidnapping of Africans while denying the extermination of Native Americans and the general violence that accompanies the creation, or re-creation, of national collectives. While the film is supposedly against war, the film ignores the perpetual "wars" involved in nation-building in addition to the particular pain and suffering that black slaves endured to ensure the leisure, pleasure, and comfort of white plantation owners. By locating the roots and sources of violence, chaos, and danger elsewhere, away from the South, away from the ideal nation, and in the black body, Griffith is able to celebrate the Klan's activities as heroic, redemptive, and conciliatory. For Griffith, Progress occurs through a re-birth that repeats, but absolves, violence against people of color and the related

$\begin{array}{ll}30 & \text { See (Sharpe 2016). } \\ 31 & \text { See (Williams 2001, p. 36). }\end{array}$ 
violence involved in nation-building. ${ }^{32}$ To use Frank Wilderson's language, we might say that Griffith's controversial film attempts to dramatize a racial conflict, which is "a rubric of problems that can be posed and conceptually resolved" but ultimately betrays the racial order as an antagonism or "an irreconcilable struggle between entities, or positions, the resolution of which is not dialectical but entails the obliteration of one of the positions." ${ }^{33}$

While The Birth of a Nation may seem outdated and irrelevant a century after its release, persistent conditions, realities, and fantasies suggest otherwise. Here I am not only thinking of the recent expressions of white supremacist violence (Dylan Roof shooting nine members of a black church, rallies in Charlottesville and other cities to take back America and safeguard whiteness, incessant State and extrajudicial violence against threatening black bodies) or the election of a President who encourages and galvanizes the more explicit, and less deniable, forms of white supremacy. I am not only thinking about the recent spate of films and television series that handle US slavery in some manner-Django Unchained, 12 Years a Slave, The Birth of a Nation (Nate Parker's 2016 version), Roots, and Underground. I am also thinking about how the logic of racial redemption operates in everyday culture, particularly in cinema. This mechanism works, with varying degrees of success, to "rescue" us from the horrifying dimensions of slavery, the afterlife of slavery, and anti-blackness more generally. The will to redeem, restore, and bring back some plentiful past denies the opaque underside of any social order; the inverse commitment to a coherent future that would compensate for, and make right, the injustices of the past assumes a notion of temporality that black experience challenges (insofar as the past is never past, the present is often a broken repetition of the past). ${ }^{34}$ In the remainder of this essay, I contend that Django Unchained operates within the framework of a rescue narrative, but in a manner that uses this genre to open the viewer to the excessive violence that conditioned slavery and the emergence of the American project, violence that is explained away in The Birth of a Nation. ${ }^{35}$

Tarantino's 2012 film, Django Unchained, encompasses a variety of genres-spaghetti western, plantation film, interracial buddy film, Blaxploitation, and romantic rescue story-as it samples, rewrites, and pokes fun at Griffith's antecedent work. ${ }^{36}$ The film's plot centers around the endeavors of a slave named Django (played by Jamie Foxx) to reunite with his wife Broomhilda Von Shaft (played by Kerry Washington) in the wake of being auctioned off and separated from his beloved. In the opening scene, Django is liberated from a coffle by Dr. King Schultz (Christoph Waltz), a German bounty hunter. Schultz promises to "give" Django his freedom on the condition that Django helps him find and capture a series of outlaws. Consequently, the eponymous character's incipient freedom is made possible by an obligation that requires him to punish those outside the law, a position that to some extent defines the slave, a position that Django can never completely escape. The contract between the two characters morphs as Schultz develops an obligation to help Django find Broomhilda, a commitment that turns the German hunter into a sidekick, thereby inverting the interracial buddy formula. ${ }^{37}$ Their search for Broomhilda leads them to Candieland, a plantation named after the owner Calvin Candie-played by Leonardo Dicaprio. While the name "Candieland" invokes sweetness, leisure, and pleasure, much of the film's violence occurs here suggesting that we cannot disentangle pleasure from horror on the field of the plantation. As I argue here, Django's departure from Birth-even as both enact a rescue fantasy-is in the former's depiction of anti-black violence that undergirds and haunts US history;

32 For a brilliant analysis of how Birth of a Nation shows the relationship between democracy, national sovereignty, and violence (or the sovereign violence that haunts the democratic project, constitutional law, etc.), see (Curtis 2016, pp. 68-86).

33 See (Wilderson 2010, p. 5).

34 See for instance (Snead 1998, pp. 62-81).

35 For some, this excessive violence is what makes Django Unchained cartoonish, unhistorical, and unable to address the everydayness of slavery and its power relationships. See for instance (Reed 2017). I speak more about this below.

36 The language of sampling is deliberate and an allusion to the fact that Tarantino's style, his practice of citation and homage to previous films and genres, is similar to that of the DJ. See for instance (Rennett 2012, pp. 391-409).

37 See (Guerrero 1993, pp. 113-56). 
in fact, black suffering stands out, and interrupts the viewer, when contrasted to Django's heroic and vengeful slaughtering of white enslavers.

The opening scene prompts the viewer to confront the physical marks of slavery on black bodies and flesh. As we hear the theme song from the original Django and initially stare into a rocky, semi-desolate terrain, the camera pans downward toward a mobile coffle of chained slaves which includes Django. Once these captive bodies enter the frame, "driven" by the Speck brothers, the viewer cannot evade the scars and cuts on their backs. In other words, Tarantino begins with a vivid, somatic reminder that, in the words of Dr. Schultz, slavery "is nasty business." ${ }^{\prime 38}$ As the opening scene continues, we experience an oscillation between close up shots of black men being slowly dragged across a desert-like landscape and long shots that position these roving slaves against the broader backdrop of the landscape. This juxtaposition invites the viewer to think about the relationship between coerced black labor, the appropriation of "uninhabited" territory, frontier settlement, and US expansion. (Perhaps the barrenness of this introductory scene invokes the erasures of indigenous peoples and forms of life. The slow walking or dragging that occurs-walking that resembles the life/death of zombies-while the opening credits appear compel the viewer to sit with and patiently contemplate the pernicious relationships being invoked against the milieu of the frontier.) When Schultz interrupts the cavalcade, and before he ultimately frees Django and the other slaves, we witness the shock and horror on Schultz's face once he sees the assemblage of scars on Django's back. ${ }^{39}$ Immediately before witnessing the German bounty hunter's horrified response, we see him releasing the chain from Django's ankle, the camera focusing in on the deep gash that the iron has impressed on black flesh. Here one should think of the oft-cited distinction that Spillers makes between the body and the flesh in the context of slavery. Whereas the body assumes a relative coherence and a form, the flesh is the black stuff or matter that slavery reduces black life to. According to Spillers, "Before the 'body' there is the 'flesh,' that zero degree of social conceptualization that does not escape concealment under the brush of discourse or the reflexes of iconography. If we think of the 'flesh' as primary narrative, then we mean its seared, divided, ripped apartness, riveted to the ship's hole, fallen, or escaped ... the calculated work of iron, whips, chains, knives, the canine patrol, the bullet." ${ }^{\prime 40}$ The repeated shots of rips and cuts to, and in, the black body in the opening scene suggest that the film's narrative will be haunted by what Spillers calls a "hieroglyphics of the flesh."

The remainder of the film could be described as Django's transition from flesh to body, from an enslaved to a liberated subject. And to some extent Django remains in this liminal space. He is repeatedly set apart from other slaves but his relationship to whites oscillates between authority and subordination, a predicament mediated and conditioned by his affiliation with Schultz, a relationship that is also in flux. As Terri Francis points out, "Django Unchained's ancillary characters, the nameless slaves, look at Django a lot and at length, their gazes drawing our attention to and sparking out admiration of our not-quite free badman's sense of self-fashioning and self-regard." ${ }^{41}$ While Django appears to make a successful shift from captive body to liberated hero-a shift visualized through his clothing and style, his being trained to punish and kill outlaws, and the revenge he enacts on former masters-this linear shift is troubled by flashbacks of punishment and torture. For instance, when Django first describes to Schultz his plans to find Broomhilda, the conversation is interrupted by an image of Django with a steel bit on his face and the sound of Old Man Carrucan castigating his disobedient slave. The steel bit, among other signifiers, reminds the viewer that the slave occupied the gap/void between Human and animal within a white supremacist imaginary. ${ }^{42}$ This flashback

\footnotetext{
See (Tarantino 2012).

9 For an insightful reading of Schultz's response (which combines outrage and compassion), see (Francis 2013, pp. 34-35).

See (Spillers 2003, pp. 206-7).

1 See (Francis 2013, p. 35).

42 As Frederick Douglass describes in his well-known slave narrative, the master's horses were often treated better than slaves; in fact, slaves were beaten when they did not manage and care for horses in a manner that met the master's expectations.
} 
scene entails close up shot-counter shot sequences in which the speaking master subject is contrasted with the muzzled slave. The back and forth quality of these close-up shots suggests a strange intimacy or interpersonal relationship, one that refuses any stable division between intimacy and violence. And the whiteness or white light that hovers in the background prompts us to think about how a certain investment in whiteness (as horizon, as atmosphere, as ontology) makes this violence against black bodies possible and acceptable.

We continue to experience the affective work of flashbacks while the two protagonists infiltrate the plantation of Big Daddy Bennett in pursuit of the Brittle brothers, Django and Broomhilda's former enslavers. Even as this Tennessee plantation turns into a site of revenge for Django (he shoots John Brittle and whips his brother, Lil Raj), the plantation scenes also visualize and render audible the everyday forms of suffering endured by slaves. Once Django, with the assistance of a female slave named Betina, spots one of the Brittle brothers, we are immediately taken back to Broomhilda and Django's previously failed attempt to escape; this unsuccessful escape sequence is intercut with images and sounds of Broomhilda being whipped by Brittle for her dissidence. The sound of the whip's lash combined with her unsettling cry replace, or stand in for, our ability to see the physical marks on her back, marks that appear later at the Candieland mansion. The sound of the black female cry is repeated as Little Jody is dragged by Lil Raj, tied to a tree, and prepared for a lashing by Big John. Like the flashback of Broomhilda's punishment, the materiality of Jody's cry disrupts and haunts us; it cannot be easily folded into a linear, coherent narrative. Furthermore, the shriek more generally, as Moten points out, "is testament to the fact that objects [or objectified beings] can and do resist." 43 Alongside the sound of Little Jody's experience of quotidian terror, we hear John quoting passages from the Bible and see what look like pages from the bible taped to this clothing. In a different manner than Griffith's film, Tarantino provides a vivid picture of how Christianity is entangled with, and literally stuck to, the formation of anti-black violence and master/slave antagonisms. Similarly, the 'Big Daddy' plantation scene responds to Griffith's depiction of this space as idyllic and amiable before the civil war. This response is solidified when we briefly view Ellis Brittle's blood spatter on the white cotton. The red/white contrast refuses the purity ascribed to the idea of whiteness, US origins, etc. In addition, the juxtaposition of blood and cotton, in a plantation field populated by coerced labor, reminds us of Marx's claim that "capital comes dripping head to foot, form every pore, with blood and dirt." 44

Django Unchained, as the viewer experiences in the Tennessee plantation segment, depicts slavery as a horrifying set of arrangements and relationships. In fact, horror is a trope and aesthetic style that operates throughout the film. According to Adilifu Nama, most of the discussions about the genres included in Tarantino's film downplay the significance of Gothic horror. As Nama points out, "Although much has been made of Django Unchained as a unique examination of American enslavement in the form of a spaghetti western, rather the aesthetic excesses of the Gothic are employed to address the conventional horrors of black subjugation in antebellum America ... In the long run and overall, Django Unchained is a Gothic horror film. ${ }^{\prime 45}$ Even though there is no need to reduce the film to one genre, underscoring this quality of Django draws our attention to various aspects: specters (the ghostly images of Broomhilda that appear to Django), skeletons, the severed ears of slaves used as currency during card games, the "fusion of laughter and terror," 46 absurdity, and ridiculous expressions of violence. While the excessive style associated with horror always threatens to take away from the gravity and accuracy of the thing being represented, exaggerated depictions can reveal, and contest, the ways in which violence gets written out of certain spaces and arrangements. They can magnify and amplify what remains hidden, unsaid, or disavowed. The Gothic form in Tarantino's film reflects

\footnotetext{
3 See (Moten 2003, p. 1).

44 See (Marx 1976, p. 926).

45 See (Nama 2015, pp. 112, 117).

46 Ibid., p. 109.
} 
the absurdity of life under the regime of slavery as well as the limitations of representing mundane forms of trauma in some accurate, reasonable manner.

One experiences the "fusion of laughter and terror" that Nama associates with Gothic horror in the Klansmen scene, a sequence that alludes to the triumphant Klan raids in Birth. While hunting for Django and Schultz on horseback, Bennett and his companions get into a comical argument about the discomfort of the masks. It might seem cruel to provoke laughter in a scene that includes the Klan, especially for those who view this group as "one of the most notorious racist organizations and staunchest supporters of racial hatred and violence against black folk." 47 Yet laughter is not necessarily an evasion of pain and suffering; in fact, as Ralph Ellison points out, there is often an "inescapable conjunction of laughter and pain." 48 Laughter, in some circumstances, is a response to, and expression of, painful tensions and incongruities that cannot be resolved or explained away. The cinematic play between laughter and terror, or comedy and violence, prompts the viewer to pause, step back, and question his/her reaction to a particular scene or event. This pause and moment of reflection in the Klansmen scene allows one to identify anguish in the midst of laughter. For instance, the complaint about not being able to see in the recently made masks stands out in contrast to the significance of patrolling, or keeping watch over, black bodies under slavery. The concerns made by the Klansmen about not being able to breathe give us pause in light of the fact that Birth ties the emergence of the Klan to the lynching of dangerous blacks, a form of punishment that involves being choked by a noose.

The intersection of laughter and violence in this bizarre proto-Klan scene opens up to a broader discussion involving what Saidiya Hartman describes as the relationship between pleasure, entertainment, and suffering within the regime of slavery. ${ }^{49}$ We witness and hear this constellation in the Mandingo fighting scene where the groans and blood-drenched flesh of black men are juxtaposed to the delight and amusement of spectators (actually the responses to the brutality range from indifference to shock to a kind of erotic arousal). As Nama points out, it is important that this fight to the death happens in "front of a warm and inviting fireplace" in a manner that highlights the tension between pleasure and horror, or coziness and terror. Nama writes, "Although the historical reality of slave fights to the death for white entertainment is more myth than reality, as a racial metaphor, however, the Mandingo fight perfectly articulates the fusion of dread and delight, abjection and desire that underscores the appetite for violence and erotic sadism that was black enslavement." 50 Whereas Griffith imagines the black buck as the source and locus of violence, Tarantino shifts our attention to the economy of violence, desire, and pleasure that contributed to the formation of enslaved and slave-holding subjects. In addition, as Nama describes, we might read the Mandingo fighting sequence as a "racial metaphor for the fetishized black [athletic] body of today." ${ }^{11}$ Not only does this reading refuse progressive narratives that would locate the themes and tropes visualized by this segment to a bygone past. It also indicts the audience of Django (and professional football) as complicit in the process of deriving some kind of amusement from consuming images, and experiences, of pain and suffering. The issue for me is not whether we should or can eschew the relationship between enjoyment and pain but how this intersection, when expressed through various cinematic strategies, might unsettle and discomfit the viewer.

The language of being unsettled and rendered uncomfortable invokes the trope of home with all of its connections to intimacy, tenderness, familiarity, etc. Recall that Birth riffs on certain images of home- the South as home; the plantation as a cozy, intimate space; the house as a site of amity between loyal slaves and benevolent masters; the peaceful home under attack by black soldiers; the rural $\log$ cabin as a retreat from black hordes; the bond between the Stoneman and Cameron families as a

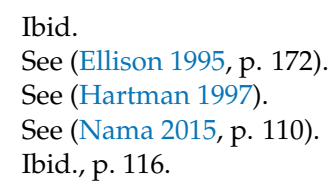


metaphor for the bond between North and South, momentarily broken by a civil war; the civil war depicted as a family affair. It is this innocent sense of home that Tarantino interrupts, most notably in the Candieland segments where Django and Schultz deceptively attempt to purchase Broomhilda. In the dinner scene, for instance, we see Candie and the servant Stephen (played by Samuel Jackson) force Broomhilda to strip and reveal her scars, which Candie likens to a painting. The manner in which Broomhilda is handled, touched, and stripped indicates the sexual availability of black women on the plantation. While Calvin's sister, Lara Lee, disapproves of this violent exhibition, she only seems to intervene because the space and time of dinner should be protected from these ghastly markings on black female flesh. This complicity of white women in the arrangement of slavery is signaled later when Django refuses to spare Ms. Lara during his final act of revenge. The dinner table is also the site where Candie uses the skull of a former slave to broach a discussion about the science of phrenology explaining the separation of the races, the submissiveness of blacks, and the advanced civility of whites. The irony of course is that while science in this scene is both an indicator and benchmark of civility and advancement, it is used to justify treating black people in a "barbaric" manner, exemplified when Candie wipes and smears blood over Broomhilda's face. As the dinner table segment shows, the interior, intimate space of the master's house is haunted and horrifying (Tarantino refuses to separate the domestic sphere from the violence that marks the master/slave relationship ${ }^{52}$ ). We experience this haunting when Schultz, while listening to a rendition of Beethoven after dinner, is disrupted by flashbacks of a slave being tortured and torn to pieces by attack dogs. This break-which is abrupt and includes the sound of a scream blending into the dog's terrifying bark - connects to earlier flashbacks and reminds the viewer that the film's unfolding narrative continues to be haunted, accompanied by painful images and sounds that cannot be easily folded into a forward movement. In other words, these breaks thwart our desires for settlement, our yearnings to find comfort in the heroic, retributive actions of the protagonist.

While Tarantino's film speaks back to Birth and its legacy by dramatizing the violent markings of slavery and anti-blackness, it is not without its own problems and limitations. One set of concerns is expressed powerfully by Adolph Reed, who excoriates the film for being an expression of neoliberal ideology. For Reed, Django ignores the structural conditions of slavery in favor of a heroic individual overcoming his cruel adversaries. It turns a system that was based on the extraction of free labor and the accumulation of wealth into a series of interpersonal relationships; the film is ultimately a romantic rescue story with a happy ending. He writes, "the deshistoricization ... makes [the] film's entirely happy ending possible ... Django Unchained ends with the hero and his lady fair riding happily into the sunset after he has vanquished evil slave owners and their henchmen and henchwomen ... The happy ending is that he and Broomhilda ride off together and free in a slaveocracy that is not a whit less secure at the moment of celebratory resolution than it was when Django set out on his mission of retrieval and revenge. ${ }^{\prime 53}$ On this reading, Django simply repeats the happy, redemptive formula of Griffith's 1915 film -Django saves his beloved Broomhilda like the Klan rescues and defends the United States from blackness. But Reed overlooks the cinematic techniques in the film that resist a simple, sanguine conclusion. The final scene contains an intentionally ridiculous quality and can be interpreted as a parody of western films and Hollywood cinema more generally- the Candieland mansion explodes while Django stands in the midst of the explosion with his sunglasses on, unscathed by the shards of the house; he performs a kind of two step with his horse; Broomhilda exaggerates her role as the rescued "damsel." On a more serious note, when we see Django put on his glasses, an expression of cool and badassness, we are reminded of the earlier scene in which he dons the glasses to disguise his affective response to the dogs mauling the disobedient slave. Consequently, there are various techniques in the film—kitsch, excess, parody, haunting, repetition, opacity—that cut against

\footnotetext{
52 On this issue, see (Glymph 2008).

53 See (Reed 2017, pp. 2-3).
} 
the happy ending motif. In addition, the viewer must listen closely to Stephen's last words_-“You can't destroy Candieland"-words that gesture toward the afterlife of slavery, the enduring economy of violence, fantasy, and desire that regulates black life.

Spike Lee articulates a different, but related, concern with Django. For Lee, the spaghetti western genre devalues the severity of slavery, a sentiment expressed in his well-known comment that "slavery was not a spaghetti western; it was a Holocaust." ${ }^{\prime 54}$ For Lee, the very form of the film does not properly correspond to his ancestors' experience under slavery; it diverts attention away from the regime's traumatic quality. What Lee leaves out in this statement is that Django, like most films, contains a variety of genres, including Gothic horror with its emphasis on terror, specters, and death. The point here is not that the Gothic style offers a more accurate depiction of slavery but that the plurality of styles and forms introduces a kind of brokenness into the visual text, a brokenness that reflects the overwhelming and unsettling dimensions of slavery and its afterlife. Part of this "afterlife" is captured by the music in the film, a soundtrack that includes contemporary hip hop in a manner that lodges the present in the past and vice versa. Perhaps a glaring irony in Lee's critique is that his most recent film, Chi-raq, has been ridiculed for using a genre, Greek comedy, that for many people trivializes the violence and suffering in Chicago's black communities. In addition to the genre issue, Lee ignores the ways in which Django relates to Tarantino's Inglourious Basterds, a 2009 film about Nazi Germany and the Jewish Holocaust. Christoph Waltz, for instance, plays an Austrian SS officer in Ingluorious in charge of hunting down Jews; both films portray the connections between science and racism and the links between Germany and America regarding scientific racism. ${ }^{55}$ For Tarantino, slavery and the Holocaust share overlapping histories, discourses, and justifications.

There are still questions that haunt Tarantino's critical riff on The Birth of a Nation. How are black slaves in the film instruments and occasions for Django's performance of freedom and heroism? More specifically, how does the repeated torture of Broomhilda position her as the black female "mule" that Django's heroic actions depend on and are defined over against? What are we to make of all the white bodies, and streams of blood, that lay around as Django develops into a vengeful, redemptive agent? How does the fantasy of an 'ex-slave turned cowboy' successfully rebelling against cruel slave masters obscure everyday modes of resistance, refusal, escape, and endurance on the plantation? In other words, how does the sharp contrast between Django's agency and the subordination of fellow slaves lose sight of quotidian ways of subsisting in the void of social death? While these questions are left unresolved, we can be confident that Django repeats the rescue narrative form of Birth but with a crucial difference. In the repetition, a break occurs in which we are opened up to images and sounds, cries and cuts, that linger and remain with the viewer. In this way, the film "rescues" the dissonant, unsettling dimensions of history from imaginaries and narratives that routinely convert dissonance into a moment of progress or restoration. For those of us invested in black religious thought, we should take seriously the enduring relationship between blackness, anguish, and the logic of (cinematic) redemption.

Acknowledgments: I would like to acknowledge the students at Duke University in my Spike Lee and Quentin Tarantino course for their insights. I would like to especially recognize Ethan Czerniecki. Conversations with him about Tarantino and blackness studies have been very helpful in developing these arguments.

Conflicts of Interest: The author declares no conflict of interest.

\section{References}

Benjamin, Walter. 1969. Theses on the Philosophy of History. In Illuminations. Translated by Harry Zohn. New York: Schocken Books.

54 For an insightful reading of this comment, see (O'Neil-Ortiz 2015, p. 327).

55 On the relationship between the two films, see (Nama 2015, pp. 93-120). Also see (O'Neil-Ortiz 2015, p. 327). 
Bogle, Donald. 2016. Toms, Coons, Mulattoes, and Bucks: An Interpretive History of Blacks in American Films, 5th ed. New York: Bloomsbury.

Bois, Du. 1999. The Souls of Black Folk. New York: Bantam Books.

Curtis, Finbarr. 2016. The Production of American Religious Freedom. New York: NYU Press.

Dixon, Thomas, Jr., D. W. Griffith, and Frank E. Woods. 1915. Birth of a Nation. Directed by D. W. Griffith. Los Angeles: Epoch Producing Company, DVD.

Ellison, Ralph. 1995. Going to the Territory. New York: Vintage.

Francis, Terri. 2013. Looking Sharp: Performance, genre, and questioning history in Django Unchained. Transition 112: 32-45. [CrossRef]

Glymph, Thavolia. 2008. Out of the House of Bondage: The Transformation of the Plantation Household. New York: Cambridge University Press.

Guerrero, Ed. 1993. Framing Blackness: The African American Image in Film. Philadelphia: Temple University Press.

Hartman, Saidiya. 1997. Scenes of Subjection: Terror, Slavery, and Self-Making in Nineteenth-Century America. New York: Oxford University.

Jordan, Winthrop. 1968. White over Black: American Attitudes toward the Negro, 1550-1812. Chapel Hill: The University of North Carolina Press.

Keeling, Kara. 2007. Witch's Flight: The Cinematic, the Black Femme, and the Image of Common Sense. Durham: Duke University. Lott, Eric. 1995. Love and Theft: Blackface Minstrelsy and the American Working Class. New York: Oxford University Press.

Martin, Joel W. 1995. Redeeming America: Rocky as Ritual Racial Drama. In Screening the Sacred: Religion, Myth, and Ideology in Popular American Film. Edited by Joel Martin and Conrad Ostwald. Boulder: Westview Press.

Marx, Karl. 1976. Capital Vol. I. Translated by Ben Fowkes. London: Penguin Books.

Moten, Fred. 2003. In the Break: The Aesthetics of the Black Radical Tradition. Minneapolis: University of Minnesota Press. Nama, Adilifu. 2015. Race on the QT: Blackness and the Films of Quentin Tarantino. Austin: University of Texas Press. O'Neil-Ortiz, Javier. 2015. Response: Intertextuality, Politics, and the Present Tense in Django Unchained. Safundi: The Journal of South African and American Studies 16: 323-29. [CrossRef]

Reed, Adolph. 2017. Django Unchained, or, the Help: How "Cultural Politics" Is Worse than No Politics at All, and Why. Available online: http:/ / nonsite.org/feature/django-unchained-or-the-help-how-culturalpolitics-is-worse-than-no-politics-at-all-and-why (accessed on 17 December 2017).

Rennett, Michael. 2012. Quentin Tarantino and the Director as DJ. The Journal of Popular Culture 45: $391-409$. [CrossRef]

Rogin, Michael. 1985. 'The Sword Became a Flashing Vision': DW Griffith's The Birth of a Nation. Representations 9: 150-95. [CrossRef]

Sharpe, Christina. 2016. In the Wake: On Blackness and Being. Durham: Duke University Press.

Snead, James. 1998. Repetition as a Figure of Black Culture. In The Jazz Cadence of American Culture. Edited by Robert O'Meally. New York: Columbia University.

Spillers, Hortense J. 2003. Black, White, and in Color: Essays on American Literature and Culture. Chicago: University of Chicago Press.

Tarantino, Quentin. 2012. Django Unchained. Directed by Quentin Tarantino. Los Angeles: Columbia Pictures. Warren, Calvin. 2015. Black Nihilism and the Politics of Hope. The New Centennial Review 15: 215-48. [CrossRef] Weigman, Robyn. 1995. American Anatomies: Theorizing Race and Gender. Durham: Duke University Press.

Wilderson, Frank B. 2010. Red, White, E Black: Cinema and the Structure of US Antagonisms. Durham: Duke University Press.

Williams, Linda. 2001. Playing the Race Card: Melodramas of Black and White from Uncle Tom to O.J. Simpson. Princeton: Princeton University Press.

(C) 2018 by the author. Licensee MDPI, Basel, Switzerland. This article is an open access article distributed under the terms and conditions of the Creative Commons Attribution (CC BY) license (http:/ / creativecommons.org/licenses/by/4.0/). 